\title{
The palaeontological virtual collection of the University of Valencia's Natural History Museum: a new tool for palaeontological heritage outreach
}

\author{
José L. HERRAIZ1, José A. VILLENA², Andreu VILAPLANA-CLIMENT', Natalia \\ CONEJERO', Honorio COCERA', Héctor BOTELLA', Anna GARCÍA-FORNER² \& Carlos \\ MARTÍNEZ-PÉREZ ${ }^{1,4^{*}}$
}

${ }^{1}$ Institut Cavanilles de Biodiversitat i Biologia Evolutiva. C/ Catedrático José Beltrán Martínez 2, 46980 Paterna, Valencia, Spain.Carlos-Martinez-Perez@uv.es, joheca@alumni.uv.es, hector.botella@uv.es

${ }^{2}$ Museu de la Universitat de València d'Història Natural. C/ Doctor Moliner 50, 46100 Burjassot, Valencia, Spain. Jose.

Villena@uv.es, hocolapa@gmail.com,Natalia.Conejero@uv.es,Anna.Garcia@uv.es

${ }^{3}$ Universitat de València, department of Botany and Geology. C/ Doctor Moliner 50, 46100 Burjassot, Valencia, Spain. anvicli@alumni.uv.es

${ }^{4}$ School of Earth sciences, University of Bristol, Life Sciences Building, 24 Tyndall Avenue, Bristol, BS8 1TQ, United Kingdom.

* Corresponding author

Herraiz, J.L., Villena, J.A., Vilaplana-Climent, A., Conejero, N., Cocera, H., Botella, H., García-Forner, A. \& Martínez-Pérez, C. 2019. The palaeontological virtual collection of the University of Valencia's Natural History Museum: a new tool for palaeontological heritage outreach. [La colección virtual de paleontología del Museo de Historia Natural de la Universitat de València: una nueva herramienta para la difusión del patrimonio paleontológico]. Spanish Journal of Palaeontology, 34 (1), $139-144$.

Manuscript received 12 February 2019

Manuscript accepted 31 March 2019 https://doi 10.7203/sjp.34.1.15249

(C) Sociedad Española de Paleontología ISSN 2255-0550

\section{ABSTRACT}

The rise of new digitalization technologies is changing the way to access to the fossil collections for palaeontology outreach, providing new tools to preserve our important palaeontological heritage. In this sense, museums and palaeontological institutions, aware of the advantages of applying these new technologies for the accomplishment of their functions, have started to develop their own online repositories to facilitate the access to the most representative fossil of their collections. Following this trend, the aim of this work is to present the creation of the new "Virtual 3D Collection" of the University of Valencia's Natural History Museum, showing, as an example, the "Ichnofossil Collection". This new Virtual Collection has been shown as

\section{RESUMEN}

El auge de las nuevas tecnologías de digitalización está cambiando la forma de acceder a las colecciones paleontológicas para divulgar la paleontología, brindando nuevas herramientas para preservar nuestro importante patrimonio paleontológico. En este sentido, los museos e instituciones paleontológicas, conscientes de las ventajas que caracterizan el uso de estas nuevas tecnologías para el cumplimiento de sus funciones como depositarios y gestores del patrimonio paleontológico, desde hace algunos años han comenzado a crear sus propios repositorios para facilitar el acceso de los ejemplares fósiles más representativos de sus fondos. Siguiendo esta tendencia, el objetivo de este trabajo es presentar la creación de la nueva "Colección Virtual 3D" 
a powerful tool for the preservation and dissemination of our palaeontological heritage throughout its free publication in online repositories.

Keywords: Virtual Collection, 3D, ichnofossils, palaeontological heritage. del Museo de la Universitat de València de Historia Natural, presentando como ejemplo la "Colección Icnofósiles". La creación de esta nueva Colección Virtual se presenta como una potente herramienta de conservación y difusión de nuestro patrimonio paleontológico a través de su publicación gratuita en repositorios online.

Palabras clave: Colección Virtual, 3D, icnofósiles, patrimonio paleontológico.

\section{INTRODUCTION}

The University of Valencia's Natural History Museum (MUVHN) differs from other traditional museums and museum collections in the nature of its historical and scientific collections (García-Forner \& Márquez-Aliaga, 2015). In this sense, the MUVHN preserves thousands of specimens grouped in 32 main collections of significant scientific and patrimonial value, being the most important, in number of specimens, the palaeontological collection inherited from the former Geological Museum of the University of Valencia.

As other entities do, due to the limited exhibition space, the MUVHN selects the elements of its permanent expositions mainly based on scientific and/or didactic criteria, showing the most representative and visual elements, and leaving most of their collections at their storage rooms. In this context, some kinds of fossils are systematically under represented in the exhibition halls due to their size, their special maintenance conditions, or their complex interpretations for the general public. For instance, microfossils are usually too small to be visualized on the naked eye; holotypes are rarely exposed due to the special conditions they require for their storage; or ichnofossils that need a spatial interpretation for their understanding. It is important to remark that these criteria can be extrapolated to any museum, museum collection, university or investigation centre with palaeontological collections.

Nevertheless, in the last decades, the management of the palaeontological heritage has experienced an important technological revolution that has mainly affected the accessibility, preservation, engagement, study and protection of this heritage. Some of the main aspects that are motivating this revolution are the use of non-intrusive scanning and digitalization techniques for the development of 3D models (Llácer \& Fortuny, 2016), as well as the implementation of virtual collections (Saorín et al., 2016). Amongst the most widespread techniques for 3D model generation we can highlight: (1) tomography techniques using Synchrotron, micro-CT or CT scans (Cunningham et al., 2014); and (2) surface modelling using laser scanning, light scanning or photogrammetry (Falkingham, 2012; Mallison \& Wings, 2014). Although all these techniques are known for decades, the expansion of specialised 3D-model generation software (without the need of any specific training or big economical investment), along with the development of numerous online platforms to store and visualize these models, are introducing a new way for 3D interactive visualizations in palaeontology (Lautenschlager, 2014; Lautenschlager \& Rücklin, 2014). It is important to highlight that the increasing use of these new techniques applied to palaeontology and outreach are promoting the emergence of the so-called Virtual Palaeontology (Bates et al., 2009; Sutton et al., 2016).

Therefore, and based on the improvement of these technologies at a low cost, the present work shows the first attempt to give a real free access to the palaeontological collections of the University of Valencia's Natural History Museum through the development of our own Virtual Collection, presenting, as an example, the most notable specimens of the ichnofossil collection of the MUVHN (Márquez-Aliaga et al., 1999).

\section{MATERIAL AND METHODS}

The MUVHN's ichnofossil collection consists of more than 250 specimens representing the main ethological classifications proposed by Seilacher (1953a, 1953b). As commented above, this "invisible" collection is a typical example of a palaeontological collection unrepresented in the exhibition space, either because the lack of space or by its difficulty to explain the origin of some of these structures to the general public. However, we select this collection as our first attempt to develop the Virtual Collection because the important information hidden by this kind of fossils, together with their scientific interest that can be used as educational complements for both, the general public and students.

For the surface digitalization of the different specimens, we use photogrammetry as a low-cost technique (Mallison 
\& Wings, 2014). To capture all the surface details, as an average, around 90 pictures per side ( 5 megapixels each) were taken at 4 different angles $\left(30^{\circ}, 45^{\circ}, 60^{\circ}\right.$ and $85^{\circ}$ aprox.), with a digital camera model Sony DSCHX60V to capture all the surface details. The images were subsequently analysed with the software Agisoft Photoscan (C) for the generation of a dense point cloud and a posterior surface render (Fig. 1). The resulting models were afterwards edited with the freeware software Autodesk Meshmixer(C) to fix the different mesh errors, and saved as OBJ files to preserve the texture information. The final models were then uploaded to the online platform https:// sketchfab.com due to the possibility of freely uploading interactive 3D content that can be downloaded under Creative Commons License. Finally, the uploaded models were grouped in the Ichnofossil Collection within the sketchfab platftorm of the MUVHN, adding all the specific information accompanying to the selected specimens (scientific name, ethological category, museum number, locality and age of the sample, and a brief description of the origin of the fossil trace).

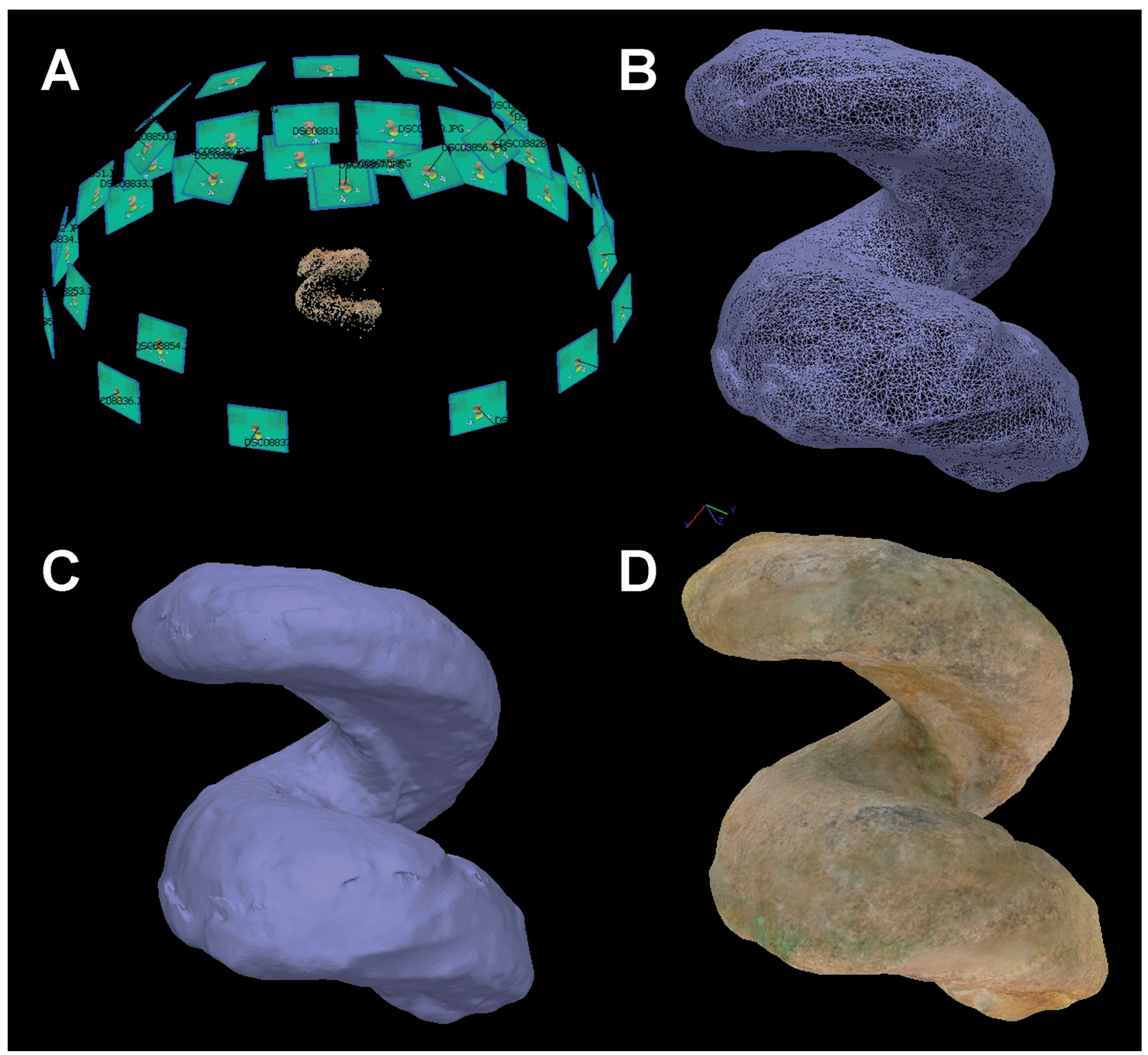

Figure 1. Photogrametry steps applied to Gyrolithes isp. (MGUV-859) from the Plioceno of Almeria (Spain) currently stored at the MUVHN. a) Sparse point cloud and camera positions. b) Dense point cloud. c) Derived mesh from the dense cloud. d) Final 3D model. 


\section{RESULTS}

From the rich MUVNH's Ichnofossil Collection, we selected and created initially nineteen 3D models of the most representative specimens from the main different ethological categories proposed by Seilacher (1953a, 1953b). Amongst the specimens digitalised we can point out three examples of locomotory traces (Repichnia), including Chelonypus isp. (turtle tracks) (Fig. 2), Cruziana isp. and Scolicia isp.; two examples of resting traces (Cubichnia), with specimens of Rusophycus isp. and Lockeia isp.; dwelling structures that reflect the life positions of organisms (Domichnia), characterised by several burrows including examples of Skolithos isp., Gyrolithes isp., Gatrochaenolithes isp. and Palmiraichnus isp.; feeding traces formed as a result of organisms disturbing the sediment in their search for food (Fodinichnia), symbolised by Rhizocorallium isp., Planolites isp. and Zoophycos isp.; or feeding traces that reflect a grazing search for food with a well-defined pattern of behaviour (Pascichnia), with characteristic examples of Spirorhaphe isp. and Dictyodora isp. In addition, several examples of biodepositions (coprolites) were also included.

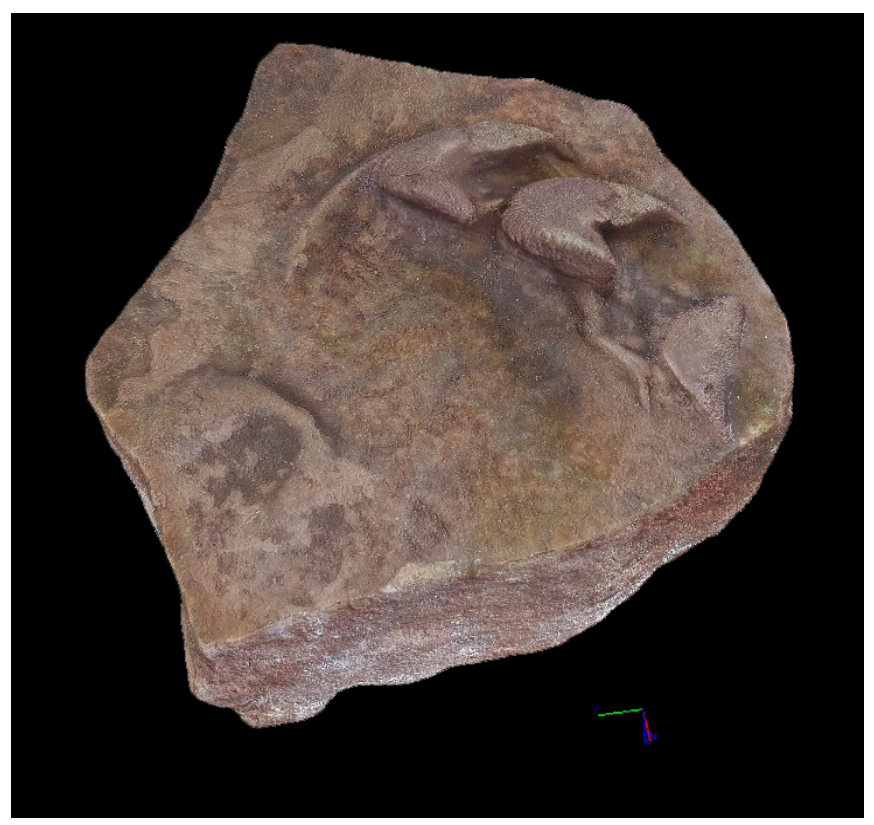

Figure 2. Final 3D model of Chelonypus isp. (chelonid track, MGUV-2314) from the Late Triassic of Domeño (Valencia, Spain) obtained after the photogrammetry process. Click on the figure at the pdf version to manipulate the 3D model.

\section{DISCUSSION}

The Virtual Collection, represented herein by the Ichnofossil Collection, symbolise the first real attempt to give free access to the palaeontological collections of the University of Valencia's Natural History Museum. This collection, characterised by more than 250 specimens with examples of all the main ethological groups established by Seilacher (1953a, 1953b), is an on-going project, where new examples for the Ichnofossil Collection and new palaeontological subcollections will be progressively added, covering different ages and taxonomic groups that are widely represented in the museum collections. In addition, this initiative highlights the advantages that these 3D-surface capture technologies bring to any museum or institution. In our particular case, the use of photogrammetry for the generation of 3D-models demonstrated important advantages comparing to other scanning techniques, such us tomographic (due to its elevated economical cost) and laser/light scans (although cheaper than tomographic techniques, they still require the acquisition and use of specific hardware). As such, the easy access to this methodology can be of great interest for any institution, becoming an exceptional tool for research and management of our rich and diverse palaeontological heritage (Díaz-Martínez et al., 2018). On the other hand, the use of open access 3D-repositories, such as https:// sketchfab.com, also presents important benefits for the museums, allowing them to develop virtual environment (exhibitions), where they are able to show most of their collections that in other circumstances would not be usually accessible to the public.

Undoubtedly, these 3D repositories are highly beneficial for everyone, from the museums themselves, by augmenting the number of pieces in exhibition; the alumni and general public, which will not only be able to "touch" and hand these pieces in a virtual environment (without the risk of damaging the original piece), but also can be download to create 3D reproductions (prototyping) for outreach; or even for investigation, where researchers can use these digital reconstructions as a source for their studies, with the possibility of high definition image capturing as well as high reliable measurement (Davies et al., 2017; Quesada et al., 2016).

In this sense, nowadays there are different universities, institutions and museums with their own fossil virtual 3D collections, both national and international. In Spain, can be highlighted the "Barcelona's Natural Science Museum Osteological Atlas" that shows their vertebrate collections in a 3D online catalogue (https://museuciencies.cat/ es/catalogo-3d-de-colecciones/); or the "Macaronesian Palaeontology Virtual Project (PAMEV)" developed by Las Palmas de Gran Canaria's University, with the main goal of showing the palaeontological heritage of the Azores, Madeira, Canary Islands and Cape Verde archipelagos by using 3D models (https://pamev.ulpgc.es). 
Similarly, in an international context, several projects and free palaeontological repositories have been recently created, such us the "GB/3D Type Fossils Online project" (http://www.3d-fossils.ac.uk/), which aims to develop a single database of type species and subspecies found in the UK and held in British collections, where the material is available under a Non Commercial Creative Commons License; the "MorphoSource project" by Duke University (USA), that allows researchers to store, organize, share and distribute their own 3D data for scientific publications; the "University of Michigan Online Repository of Fossils (UMORF)", a project of the University of Michigan Museum of Palaeontology to increase the accessibility of fossil specimens through online 3D and 2D representations (https://umorf.ummp.lsa. umich.edu); or the "MorphoMuseuM" an online journal that publishes 3D models of vertebrates, including models of type specimens (http://morphomuseum.com/), amongst others. It is important to point out that all these kind of repositories are becoming essential, not only for outreach but also for investigation, where the researchers can upload the data associated to their different publication to make them accessible (Davies et al., 2017).

\section{CONCLUSION}

The development of non-intrusive scanning and digitalization techniques for 3D model generation during the last decades have facilitated the access to this methods in an economical and easy technical way, with no needs of specialised devices or software installation requirements. These new approaches, not just for digitalization and creation of online 3D model, but also for the easy access to palaeontological collections, is motivating an important transformation in the management of the fossil collections, facilitating the access, preservation, documentation, outreach, study and protection of the palaeontological heritage. The creation of this new Virtual Collection by the University of Valencia's Natural History Museum (MUVHN) is following this trend, with the development of our own 3D repository, with the main objective of becoming not just an important tool for conservation, but also for disseminating our palaeontological heritage in a world without barriers.

\section{ACKNOWLEDGEMENTS}

This Project was partially funded (to JAV) by the Spanish Ministry of Science, Innovation and Universities via the Subprogram of Incorporation and the State Program for Promotion of Talents and their Employability. We acknowledge the comments of the two reviewers, Dr. Carmen Alvarez and Dr. Patrocinio Espigares, who have improved the final manuscript.

\section{REFERENCES}

Bates, K.T., Falkingham, P.L., Hodgetts, D., Farlow, J.O., Breithaupt, B.H., O’Brien, M., Matthews, N., Sellers, W.I. \& Manning, P.L. 2009. Digital imaging and public engagement in palaeontology. Geology Today, 25, 134139; doi: 10.1111/j.1365-2451.2009.00714.x.

Cunningham, J.A., Rahman, I.A., Lautenschlager, S., Rayfield, E.J. \& Donoghue, P.C.J. 2014. A virtual world of paleontology. Trends in Ecology and Evolution, 29, 347-357; doi: 10.1016/j.tree.2014.04.004.

Davies, T.G., Rahman, I.A., Lautenschlager, S., Cunningham, J.A., Asher, R.J., Barrett, P.M., Bates, K.T., Bengtson, S., Benson, R.B.J., Boyer, D.M., Braga, J., Bright, J.A., Claessens, L.P.A.M., Cox, P.G., Dong, X.P., Evans, A.R., Falkingham, P.L., Friedman, M., Garwood, R.J., Goswami, A., Hutchinson, J.R., Jeffery, N.S., Johanson, Z., Lebrun, R., Martínez-Pérez, C., Marugán-Lobón, J., O’Higgins, P.M., Metscher, B., Orliac, M., Rowe, T.B., Rücklin, M., Sánchez-Villagra, M.R., Shubin, N.H., Smith, S.Y., Starck, J.M., Stringer, C., Summers, A.P., Sutton, M.D., Walsh, S.A., Weisbecker, V., Witmer, L.M., Wroe, S., Yin, Z., Rayfield, E.J. \& Donoghue, P.C.J. 2017. Open data and digital morphology. Proceedings of the Royal Society B: Biological Sciences, 284, 20170194; doi: 10.1098/ rspb.2017.0194.

Díaz-Martínez, I., Citton, P., Valais, S. de \& García-Ortiz, E. 2018. La fotogrametría se convierte en una poderosa herramienta para la conservación y difusión del patrimonio paleontológico. PH: Boletín del Instituto Andaluz del Patrimonio Histórico, 26, 20-22; doi: 10.33349/revistaph. v0i0.

Falkingham, P.L. 2012. Acquisition of high resolution three-dimensional models using free, open-source, photogrammetric software. Palaeontologia Electronica, 15, 1-15; doi: 10.26879/264.

García-Forner, A. \& Márquez-Aliaga, A. 2015. Special features, functions and solutions of a University Museum: example of the MGUV. In: Congreso Internacional Museos Universitarios: Tradición y Futuro (coord. Rivera, R.D. \& García Fernández, I.). Universidad Complutense de Madrid, 207-213.

Lautenschlager, S. 2014. Palaeontology in the third dimension: a comprehensive guide for the integration of threedimensional content in publications. Paläontologische Zeitschrift, 88, 111-121; doi: 10.1007/s12542-013-0184-2.

Lautenschlager, S. \& Rücklin, M. 2014. Beyond the printvirtual paleontology in science publishing, outreach, and education. Journal of Paleontology, 88, 727-734; doi: 10.1666/13-085. 
Llácer, S. \& Fortuny, J. 2016. Herramientas de digitalización y generación de modelos 3D: Láser y fotogrametría aplicada a la paleontología. Revista de la Asociación Española de Ensayos no Destructivos, 77, 16-20.

Mallison, H. \& Wings, O. 2014. Photogrammetry in paleontology - a practical guide. Journal of Paleontological Techniques, 12, 1-31.

Márquez-Aliaga, A., García-Forner, A., Martínez, C. \& Villena, J.A. 1999. "Colección icnofósiles” del Museo de Geología de la Universidad de Valencia. In: (ed. Rábano, I.), XV Jornadas de Paleontología y Simposios de los proyectos 393, 410 y 421. Colección Temas GeológicoMineros ITGE, 26, 413-414.

Quesada, J., Aurell-Garrido, J., Gago, S., Boet, B., \& GarcíaFranquesa, E. 2016. Measurement errors in 3D models used in osteometric data research with freeware: a test using skulls of the Algerian hedgehog (Atelerix algirus). Vertebrate Zoology, 66, 411-418.
Saorín, J.L., de la Torre-Cantero, J., Meier, C., Díaz, D.M., Castillo, C.R. \& de León, A.B. 2016. Creación, visualización e impresión $3 \mathrm{D}$ de colecciones online de modelos educativos tridimensionales con tecnologías de bajo coste. Caso práctico del patrimonio fósil marino de Canarias. Education in the Knowledge Society, 17, 89-108; doi: 10.14201/eks201617389108.

Seilacher, A. 1953a. Studien zur Palichnologie, I. Über die Methoden der Palichnologie. Neues Jahrbuch für Geologie und Paläontologie. Abhandlungen, 96, 421-452.

Seilacher, A. 1953b. Studien zur Palichnologie, II. Die fossilen Ruhespuren (Cubichnia). Neues Jahrbuch für Geologie und Paläontologie. Abhandlungen, 98, 87-124.

Sutton, M., Rahman, I. \& Garwood, R. 2016. Virtual Paleontology-An overview. The Paleontological Society Papers, 22 (Virtual Paleontology), 1-20; doi: 10.1017/ scs.2017.5. 